(С Псарьова М.Д., 2020 р.

http://orcid.org/ 0000-0002-0575-2629

https://doi.org/10.34142/23128046.2020.48.09

М.Д. Псарьова

\title{
НОРМАТИВНО-ПРАВОВЕ ЗАБЕЗПЕЧЕННЯ ОСВІТИ ДІТЕЙ 3 ПОРУШЕННЯМИ ПСИХІЧНОГО РОЗВИТКУ У США В ДРУГІЙ ПОЛОВИНІ ХХ - НА ПОЧАТКУ ХХІ СТОЛІТТЯ
}

Якість інклюзивної освіти є показником гуманного та толерантного ставлення суспільства до людей з особливими освітніми потребами. У зв'язку з підтриманням Україною у 2009 рочі Конвениї ООН про права інвалідів, збільшенням в останні десятиліття кількості дітей 3 порушеннями психічного розвитку, зокрема з розладом спектру аутизму, та через проблеми такої дитини у поведінщуі, соиіалізації, комунікащії та нерідку іï академічну неуспішність, питання якісного включення даної категорії учнів до загальноосвітнього середовища на сьогодні постають дуже гостро, а відтак викликають науковий інтерес у вітчизняних дослідників та освітян. Оскільки США є країною, яка одна з перших звернулася до ідеї інклюзивної освіти та на сьогодні має успішну практику ї̈ організаиії, вважаємо доиільним звернутися до досвіду иієї країни, зокрема дослідити нормативноправове забезпечення освіти дітей з порушеннями психічного розвитку в другій половині XX - на початку XXI століття.

Мета статті - розкриття нормативно-правової бази організаиіі освіти дітей з порушеннями психічного розвитку, зокрема з розладом спектру аутизму, виявлення принципів та особливостей функціонування інклюзивної освіти у визначених хронологічних межах. Для вирішення поставленої мети у статті були використані методи: загальнонаукові (аналіз, синтез та узагальнення) та історико-педагогічні (структурнохронологічний та ретроспективний аналіз).

У статті проаналізовано нормативно-правове забезпечення освіти дітей з порушеннями психічного розвитку (зокрема, розладу спектру аутизму) у період з другої половині $X X$ до початку XXI століття. Схарактеризовано основні принципи здійснення інклюзивної освіти та визначено особливості ії функціонування, такі як: створення континууму альтернативних розміщень, індивідуального навчального плану та плану 504, очінювання дітей з розладом спектру аутизму, використання допоміжних технологій та сервісів переходу тощо.

Ключові слова: інклюзивна освіта, порушення психічного розвитку, розлад спектру аутизму, США, друга половина XX-початок XXI століття. 
Psarova M.D. Law regulation of education for children with mental disorders in the USA (second half of XX-the beginning of XXI century). The quality of inclusive education is an indicator of the humane and tolerant attitude of society towards people with disabilities. In 2009 Ukraine ratified the UN Convention on the Rights of Persons with Disabilities, therefore the interest in education for people with mental and physical impairments in inclusive educational settings has grown significantly in the last decade. Today the issue of providing quality educational services for people with mental disorders, including children with autism spectrum disorders, is very pressing. Due to significant behavioral problem, socialization, communication and frequent academic failure in such children, educators face a lot of problems working with them in inclusive schools. The USA is one of the first countries that adopted the idea of inclusive education and today has successful practices of its organization, so we consider it is expedient to learn from the experience of this country, in particular, to study the law regulations of education for children with mental disorders in the second half of the XX - XXI centuries.

The purpose of the article is to analyze the legal and regulatory framework for the organization of education for children with mental disorders, autism spectrum disorder in particular, to identify the principles and special features of functioning of inclusive education in the selected chronological limits. To achieve this goal we used such methods as general scientific (analysis, synthesis and generalization) and historical and pedagogical (structural-chronological and retrospective analysis).

The article analyzes the legal provision of education for children with mental disorders (autism spectrum disorder in particular) in the period from the second half of the XX to the beginning of the XXI century. We highlighted the basic principles of inclusive education and described some special features of its functioning, such as the creation of a continuum of alternative placements, individual educational program and plan 504, assessment of children with autism spectrum disorders, use of assistive technologies, transition services, etc.

Keywords: inclusive education, mental disorders, autism spectrum disorder, USA, second half of XX - beginning of XXI century.

Вступ. Перший крок на шляху до інклюзивної освіти Україна зробила у грудні 2009 року, ратифікувавши Конвенцію ООН про права інвалідів, яка $\epsilon$ основним міжнародним документом щодо забезпечення якісної освіти, соціалізації та інтеграції дітей з особливостями психофізичного розвитку. Вже у 2011 році у нашій країні було прийнято Закон «Про затвердження Порядку організації інклюзивного навчання у загальноосвітніх навчальних закладах», у відповідності з яким дитина з особливими освітніми потребами має право за місцем свого проживання відвідувати класи з інклюзивною формою навчання. 
За складністю організації навчання даної категорії, учні з розладом спектру аутизму займають особливе місце серед учнів 3 іншими порушеннями психофізичного розвитку. Через проблеми у соціальній взаємодії та мові, поведінці, одноманітні інтереси та нерідко, як зазначено у DSM - V, коморбідні порушення інтелектуального розвитку включення такої дитини до загальноосвітнього середовища $\epsilon$ доволі непростим процесом (Diagnostic and Statistical Manual of Mental Disorders, 2013).

У порівнянні з західними країнами Україна робить тільки перші невпевнені кроки на шляху до реалізації інклюзивної освіти, тому звернення уваги до теорії та практики інших країн $є$ необхідним для більш ефективного навчання дітей із особливими освітніми потребами, зокрема 3 розладом спектру аутизму. Оскільки США є країною, яка одна із перших впровадила ідеї інклюзивного освітнього простору та на сьогодні має найбільш успішну практику його організації, вважаємо доцільним звернення до досвіду цієї країни. У сучасній педагогічній науці проблемі організації освіти дітей 3 порушеннями психічного розвитку присвячена значна кількість наукових праць. Зокрема, вивченням історико-педагогічних аспектів організації інклюзивної освіти у США займалися такі дослідники: Дж. Беккен (J. Bakken), Е. Бьонз (Е. Burns), М. Винзер (M. Winzer), Дезінгер (J. Desinger), М. Йелл (M.Yell), А Катсианніс (A. Katsiyannis), А. Ловрей (A. Lowrey), К. Мутуа (К. Mutua), Ф. Обіакор (F. Obiakor), А. Роратори (A. Rotatori), Дж. Сідерс (J. Siders), Р. Скіренбергер (R. Scheerenberger).

Мета статті полягає у розкритті нормативно-правової бази організації освіти дітей з порушеннями психічного розвитку, зокрема з розладом спектру аутизму, характеристиці принципів та особливостей функціонування інклюзивної освіти у визначених хронологічних межах.

Методи дослідження. У роботі було використано такі методи: загальнонаукові (аналіз, синтез та узагальнення) та історико-педагогічні (структурно-хронологічний та ретроспективний аналіз).

Результати. Вивчення та узагальнення науково-педагогічних джерел свідчить про те, що вперше про рівність людських прав на Північноамериканському континенті згадується у Декларації про незалежність (1776 рік) (The Declaration of Independence, July 4, 1776). У зазначеній Декларації наголошується: «Усі люди були створені рівними, так як Творець наділив їх певними невід'ємними правами, серед яких є життя, свобода та прагнення до щастя» (The Declaration of Independence, 1776). Під «рівністю» мається на увазі незалежність тринадцяти колоній Північної 
Америки від влади Великої Британії та право на створення рівної серед інших держави - Сполучених Штатів Америки. Хоча цей документ ще не мав на увазі рівність прав людей 3 особливостями психічного та фізичного розвитку, але початок довгої боротьби за права різних верст населення у США був покладений (The Declaration of Independence, 1776).

У другій половині XIX століття у США з'являється інтерес до менш захищених верст населення. Так, на Півночі країни зароджується рух за відміну системи рабовласництва, який проходив під гаслом «Всі люди народжуються рівними», наслідком якого $є$ підписання президентом А. Лінкольном наказу про відміну рабства. Для дітей з особливостями психічного розвитку у цей час у невеликій кількості починають відкриватися перші школи, серед яких найбільш відомими були: Массачусетська школа для ідіотичної молоді (Massachusetts School for Idiotic and Feebleminded Youth) під керівництвом C. Хoy (S. Howe) та школи видатного французького лікаря Е. Сегена (Е. Seguin), у яких дослідник поширював свій передовий європейський досвід. Крім цього, 3 метою організації фахівців у сфері навчання, виховання та лікування Е. Сегеном створюється асоціація з питань розумової відсталості, яка сьогодні має назву Американська асоціація 3 інтелектуальних порушень та порушень розвитку (American Association on Intellectual and Developmental Disabilities, AAIDD).

Незважаючи на перші успішні спроби навчати людей з психічними порушеннями у ті часи, заклади, у яких діти мали змогу отримати освіту, були дуже рідкими. Метою таких закладів було не навчання, а забезпечення базових потреб дитини. Зазвичай батькам, у яких народжувалась особлива дитина, пропонувалося віддати ії до інтернату. Щоб захистити суспільство від людей $з$ психофізичними розладами інтернати ретельно охоронялися, тому зустріти таку людину на вулиці було практично неможливо (Rotatori, 2011).

Початок XX століття не приніс позитивних змін щодо організації освіти людей 3 особливими освітніми потребами. Ситуація навіть погіршилась через масове розповсюдження ідей євгеніки. Цей напрям зародився у Англії наприкінці XIX століття завдяки працям відомого психолога та соціолога Ф. Гальтона, двоюрідного брата Ч. Дарвіна. Свгеніка (від гр. «eugenics» - благородний) - це учіння, метою якого було покращення генофонду людини за допомогою селективного розмноження. Ідеї цього учіння у США відобразилися у Законі «Про стерилізацію» (Model Eugenical Sterilization Law), у відповідності з яким «соціально неадекватному» класу 
людей не дозволялося мати нащадків. До соціально неадекватного класу (social inadequate class) належали: недоумкуваті, божевільні (психопати), злочинці, люди 3 епілепсією, залежні від алкоголю (у тому числі від наркотичних речовин), хворі (на туберкульоз, сифіліс, лепру (проказу) та 3 іншими хронічними, інфекційними хворобами), сліпі (у тому числі люди 3 серйозними порушеннями зору), глухі (у тому числі особи з серйозним порушенням слуху), деформовані (у тому числі каліки), залежні (діти-сироти, нероби, бездомні, бродяги та жебраки). Такі люди були непотрібними суспільству: вчити та виховувати таких громадян держава не хотіла (Model Eugenical Sterialization Law, 1922).

Освітні реформи для дітей із особливими освітніми потребами починають проводиться 3 60-х $\mathrm{pp}$. XX століття. У ці роки у США відбуваються значні соціальні, політичні та економічні зміни, які готують фундамент для становлення якісної освіти для всіх дітей без виключення. Першим кроком у боротьбі 3 дискримінацією в освіті стала справа афроамериканських дітей 1954 року, яка отримала назву «Браун проти ради 3 освіти» (Brown v. Board of Education, 1954). Після завершення справи афроамериканські діти отримали право на навчання у загальноосвітніх школах разом зі своїми однолітками, що призвело до початку процесу закриття спеціальних шкіл для таких дітей. Ми згодні 3 дослідниками Б. Ашбакер (B. Ashbacker), М. Вінзер (M. Winzer) та A. Рораторі (A. Roratory) у тому, що справа 1954 року підготувала підгрунтя для подальших змін у сфері освіти дітей з особливими освітніми потребами (Rotatori, 2011; Winzer, 2009).

Права людей із психічними порушеннями починають активно захищати під час правління президента Дж. Кеннеді (1961-1963) та віцепрезидента Х. Хемфрі (1964-1968). Урядовці мали особистий інтерес до проблеми освіти дітей із психічними розладами, так як сестра першого та онука другого були народжені з розумовою відсталістю. Так, Дж. Кеннеді стає ініціатором створення групи експертів 3 питань розумової відсталості (Presidental Panel on Mental Retardation, 1961), метою діяльності якої були розробка плану боротьби з цим розладом (програми лікування, навчання, підготовки до працевлаштування) та правовий захист. У 1963 році виходить Закон «Про розумову відсталість та побудову центрів психічного здоров'я» (Mental Retardation and Community Mental Health Centers Construction Act of 1963), який стає початком процесу деінституалізації. У зазначеному Законі зафіксовано зобов'язання держави щодо надання грантів для побудови 
науково-дослідних центрів для проведення досліджень ментальних порушень та навчання дітей з такими порушеннями (Mental Retardation and Community Mental Health Centers Construction Act, 1963).

Слід наголосити на тому, що більшість дітей 3 розладом спектру аутизму у той час відносили до категорії «розумова відсталість», так як діагноз «аутизм» (infantile autism) вперше потрапив до медичного довідника, a саме DSM-III, тільки у 1980 році (Rotatori, 2011). Тому такі видатні дослідники у сфері аутизму як біхевіорист I. Ловаас та Е. Шоплер засновник методу ТЕАСНH (Treatment and Education of Autistic and related Communication-handicapped Children y пер. терапія та навчання дітей 3 аутизмом та пов'язаними комунікативними порушеннями) мали змогу проводити свою наукову роботу саме завдяки цим грантам.

У ході дослідження встановлено, що протягом наступного десятиліття по всій Америці відбуваються десятки судових засідань стосовно способу навчання дітей 3 особливими потребами, найбільш значущими 3 яких A. Рораторі (A. Rotatori) виділив два: Пенсильванську асоціацію дітей 3 розумовою відсталістю проти Пенсильванського союзу (Pennsylvania Association for Retarded Children (PARC) v. Commonwealth of Pennsylvania, 1972) та Мілз проти ради з питань освіти (Mills v. Board of Education, 1972).

У першому випадку PARC подає позов на захист прав людей iз розумовою відсталістю проти штату Пенсільванія. Прихильники PARC відстоювали право дітей із розумовою відсталістю на навчання у державних школах. За рішенням суду було дозволено таким дітям навчатися у школах Пенсільванії за кошти штату. На другому судовому засіданні, Мілз проти ради 3 питань освіти, розглядалася справа дванадцятирічного афроамериканського хлопчика Піттера Мілз (Pitter Mills), якого через проблемну поведінку було виключено зі школи.

Шкільний округ намагався довести, що хлопця запросили піти зі школи через нестачу фінансів для надання спеціальної (індивідуальної) програми розвитку. Рада з питань освіти штату програла цю справу. Суд оголосив, що нестача коштів не може бути виправданням для відмови у навчанні дітям 3 особливими освітніми потребами. Згідно до цього рішення було встановлено повернути всіх дітей, яких було виключно, до школи (Rotatori, 2011).

Підкреслимо, що рішення вищезазначених федеральних судових засідань були підгрунтям для ухвалення державного Закону «Про реабілітацію» (1973 рік) (Rehabilitation Act of 1973), який забороняв дискримінацію людей з інвалідністю у будь-яких державних програмах або 
діяльності. Згідно до статті 504 (Section 504) цього Закону керівники шкіл повинні зменшувати бар'єри у середовищі, що заважають дитині 3 особливими потребами повноцінно брати участь у діяльності відповідно до навчальної програми. Важливо відмітити, що Закон «Про реабілітацію» 1973 року - не є законом про спеціальну освіту та відповідні послуги. Це Закон, який стосується громадянських прав особистості.

Він демонструє те, як дитина буде отримувати доступ до навчання, тобто які зміни необхідно зробити у середовищі, щоб задовольнити потреби особливих дітей. Стаття 504 передбачає розробку плану (504 Plan), в якому керівництво школи, вчителі, які працюють 3 дитиною, та батьки вказують, яка саме адаптація повинна проводитись для дитини (Rehabilitation Act, 1973). Серед таких адаптацій для дітей із високофункційним аутизмом Дж. Дезінгер (J. Deisinger) надає спрощені інструкції, проводить доповнення вербальних інструкцій візуальними, передбачає більшу кількість часу для закінчення контрольної роботи або домашнього завдання. Підкреслимо, що усі вищезазначені зміни у середовищі є необхідними для дитини з аутизмом, але для ефективного навчання більшої кількості з них проведення змін лише за планом 504 недостатньо (Rotatori, 2011).

Через рік у США виходить Закон «Про права сімей на конфіденційність» (Families Educational Rights and Privacy Act, FERPA), який дозволяє батькам отримувати доступ до всієї інформації стосовно їх дитини. Закони PARS, Mills, Закони «Про реабілітацію» (1973 рік) та «Про конфіденційність» (1974 рік) були підгрунтям для прийняття Закону, який найбільше вплинув на освіту дітей з інвалідністю, - першого Закону «Про спеціальну освіту».

Революційною подією у житті американських дітей із особливими освітніми потребами стало прийняття Закону «Про освіту всіх дітей 3 інвалідністю» (англ. Education for All Handicapped Children Act, EAHCA) (1975 рік), який став одним із перших законів про надання спеціальної освіти та відповідних послуг на державному рівні. Ми згодні з такими дослідниками як Ф. Обіакор (F. Obiakor) та A. Рораторі (A. Rotatori), що загальні принципи стосовно освіти людей з інвалідністю були покладені саме у цьому Законі (Rotatori, 2011).

Серед основних принципів ЕАНСА нами було визначено такі: нульова відмова (Zero reject), належна безкоштовна державна освіта (Free Appropriate Public Education, FAPE) та принцип середовища (Least Restrictive Environment). Принцип нульової відмови (Zero reject) вимагає заборону на 
виключення дитини зі школи через їі інвалідність. Другий, FAPE, гарантує надання спеціальної освіти та відповідних послуг, які мають відповідати стандартам штату та включати дошкільну й середню освіту. Реалізація останнього важливого принципу передбачає створення середовища, яке забезпечує можливість навчання дитини з особливими освітніми потребами разом із однолітками, які мають подібні проблемами.

Підкреслимо, що для реалізації FAPE, тобто належної освіти, для дітей віком від 3 до 21 років вводилась індивідуальна програма навчання (Individualized Educational Plan, IEP), яка вже тоді розроблялася в залежності від виду розладу та індивідуальних потреб дитини. До документу IEP згідно Закону 1975 року входили такі компоненти:

- $\quad$ дані про рівень успішності дитини;

- цілі на найближчий та довгостроковий період;

надаватися дитині та ступінь включення дитини до загальноосвітнього середовища;

- $\quad$ очікувані дати впровадження спеціальних послуг;

- $\quad$ критерії, за якими можна встановити, що дитина досягла успіху (Education for All Handicapped Children Act, 1975).

У першому схваленні Закон «Про освіту всіх дітей з інвалідністю» від 1975 року вимагав розробки індивідуальної програми розвитку для дітей, що мали одну з 11-ти категорій порушень, до яких аутизм на той час ще не входив. Ми поділяємо думку Дж. Дезінгера (J. Deisingera), що у ті часи діти 3 аутизмом могли отримувати індивідуальну програму розвитку разом 3 такими категоріями, як розумова відсталість та емоційні порушення (Rotatori, 2011).

Закони «Про реабілітацію» (1973 рік) та «Освіту всіх дітей 3 інвалідністю» (1975 рік) вимагають від команди супроводу дитини реалізацію планів 504 та IEP. А. Катсианніс (А. Katsiyannis) виділяє такі відмінності між ними: перший стосується громадянських прав людини та описує зміни у середовищі, які необхідно зробити для включення дитини до цього середовища, другий є планом про надання послуг спеціальної освіти. План 504 призначений для вчителя загальноосвітніх класів, при цьому спеціальний педагог може лише надавати консультації стосовно роботи 3 дитиною. IЕР розробляється лише для 11 категорій дітей (у 1975 році) та 13 категорій (починаючи з 1990 року), а план 504 охоплює значно більшу кількість дітей (A. Katsiyannis, 1999). 
У ході дослідження встановлено, що Закон від 1975 року (ЕАНСА) був переглянутий декілька разів, найбільш значні його зміни відбулись у 1986, 1990, 1997 та 2004 роках. Розглянемо більш детально кожний із цих переглядів. Законопроєкт від 1986 року зобов'язує відповідні структури створювати індивідуальний сімейний план послуг (Individualized Family Service Plan), в якому необхідно прописувати план дій для сім'ї дитини 3 інвалідністю від народження до 36 місяців.

У 1990 році ЕАНСА було перейменовано у Закон «Про освіту людей $з$ інвалідністю» (Individuals with disability education act, IDEA). У цьому перегляді було пом'якшено термінологічні формулювання: термін «інвалід» (handicapped) чи «дитина/учень/людина-інвалід» (a handicapped child/student/person) замінено на поняття «дитина/учень/людина 3 інвалідністю» (a child/student/person with a disability), що зосереджує увагу на тому, що саме людина, а не ії інвалідність знаходиться на першому місці. Важливим для нашого дослідження $є$ той факт, що вперше в IDEA'90 з'явилася категорія «аутизм», а введення такої категорії вимагало відповідної діагностики та корекції за індивідуальною програмою навчання (IEP).

Також у 1990 році з'явилися нові послуги, серед яких: послуги переходу (transition services), допоміжні технології (assistive technology services, AT) та інші. Перші $\epsilon$ послугами, які надаються дитині у підлітковому віці з метою допомоги при переході до дорослого життя. Другі - це послуги, спрямовані на визначення технологій, які допоможуть дитині стати більш впевненою та успішною у суспільстві (Individuals with disability act, 1990). Сьогодні для дитини 3 аутизмом до допоміжних технологій належать: альтернативна комунікація (наприклад, книжки з картками PECS або голосова допомога при комунікації - voice output communication aids, VOCA), комп'ютерні інструкції (Computer assisted instructions, CAI) та такі спеціально розроблені програми, як Boardmaker, Pix-Writer, Picture-It, e-kid tools, e-kid skills та інші (Rotatori, 2011).

Необхідно звернути увагу на те, що черговий перегляд цього Закону відбувся у 1997 році. У цьому перегляді було розширено поняття FAPE, до якого з того часу належать не тільки спеціальна освіта та відповідні послуги, але й «додаткова допомога та сервіси» (Supplementary Aids and Services), які дозволяють дітям із особливими освітніми потребами навчатися разом із однолітками з типовим розвитком. Додаткова допомога та сервіси включають такі компоненти, як акомодація середовища, модифікація та допомога однолітків (peer tutoring). 
Зауважимо, що в кінці 90-х pp. ХХ століття з'явилося поняття «континуум альтернативних розміщень» (continuum of alternative placements). Поняття «альтернативне розміщення» передбачає навчання у звичайних класах, спеціальних класах, спеціальних школах, домашній інструктаж та інструктаж у лікарнях та інтернатах. Для дітей-інвалідів, розміщених у звичайних класах, за потреби, повинні надаватися додаткова допомога та сервіси, ресурсні кімнати та інструкції. Контінуум сервісів надається тоді, коли дитина не може отримати належну освіту шляхом повного включення iï до класу з однолітками з типовим розвитком. Дитина з ООП, яка отримує навчання у альтернативному середовищі, після закінчення школи зазвичай отримує диплом IEP (IEP diploma) замість атестату про завершення середньої освіти (regular high school diploma). Цей вид диплому не дозволяє вступати до закладів вищої освіти, на службу до армії та не розглядається роботодавцем як атестат про середню освіту (Burns, 2003).

Останній перегляд IDEA відбувся у 2004 році, у якому було змінено назву на «Вдосконалений Закон про освіту людей з інвалідністю» (Individuals with Disabilities Education Improvement Act, IDEIA). На основі усіх вищезазначених переглядів IDEA та Закону «No Child Left Behind Act» від 2001 року у IDEIA'04 затверджено такі основні принципи здійснення інклюзивної освіти, як: нульова відмова (zero reject), ідентифікація та оцінка без дискримінації (nondiscriminatory identification and assessment), індивідуальна програма розвитку (individualized education program, IEP), середовище, яке найменш обмежує (least restrictive environment, LRE), процесуальні гарантії (procedural safeguards), участь батьків (parental participation) та послуги переходу (transition). (Individuals with Disabilities Education Improvement Act, 2004).

У ході дослідження встановлено, що серед інших законопроєктів важливе місце для американських школярів, зокрема з особливими освітніми потребами, займає закон No Child Left Behind Act від 2001, у якому зроблено акцент на оцінювані успішності дитини. Згідно до цього законопроєкту кожен штат зобов'язується розробити тести, які дозволяли б оцінити знання, вміння та навички всіх дітей без виключення. Так як фізичні та/або когнітивні здібності дітей з особливими освітніми потребами відрізняються від здібностей дітей з типовим розвитком, команда IEP приймає рішення, яке саме оцінювання буде проходити така дитина: стандартизоване чи альтернативне. 
До першого належить регулярне оцінювання, яке надається всім дітям без інвалідності (regular assessment) або регулярне оцінювання 3 акомодаціями та/або модифікаціями, які ухвалені окремим штатом (regular assessment with accommodations and modifications). Альтернативне оцінювання (alternative assessment) дитина може здавати лише у тому випадку, якщо вона має значні когнітивні порушення. Якщо команда спеціалістів визнала необхідність складання альтернативного оцінювання, вона зобов'язана вказати причини неспроможності проходження дитиною регулярного оцінювання та зазначити вид альтернативної оцінки, який необхідно провести.

Другий акцент у NCLB було зроблено на навчанні дітей тільки за тими освітніми програмами, які науково довели свою ефективність. Наприклад, для дитини 3 аутизмом передбачено створення структурованого навчального середовища за програмою, яка орієнтована на розвиток мови, соціальних навичок, оцінку функціональної поведінки та інше (Yell, 2005).

Обговорення. Розвиток системи інклюзивної освіти у США раніше було успішно висвітлено у дисертаційному дослідженні М. Захарчук, але новизна проведеного дослідження полягає у тому, що, маючи проблеми у включенні дітей з розладом спектру аутизму до соціуму, нами було вирішено висвітлити особливості роботи саме з такою категорією дітей у США.

Висновки. Таким чином, огляд нормативно-правової бази у галузі освіти дітей із порушенням психічного розвитку у США показав, що активна увага суспільства до проблем таких дітей почала приділятися з 60 -тих років XX століття. Зокрема, були визначені принципи роботи системи інклюзивної освіти, а саме: нульова відмова (zero reject), ідентифікація та оцінка без дискримінації (nondiscriminatory identification and assessment), індивідуальна програма розвитку (individualized education program, IEP), середовище, яке найменш обмежує (least restrictive environment, LRE), процесуальні гарантії (procedural safeguards), участь батьків (parental participation) та послуги переходу (transition).

Функціонування системи інклюзивної освіти США передбачає розроблення континууму альтернативних розміщень, оцінювання дітей 3 розладом спектру аутизму, створення індивідуального навчального плану та плану 504, використання допоміжних технологій та послуг переходу.

\section{ЛITEPATУРА:}

Burns. A. Handbook for Supplementary Aids and Services: A Best Practice and IDEA Guide. Springfield: Charles C Thomas Pub Ltd. 2003, 268 p. 
Community Mental Health Act: a United States law from Oct. 31, 1963. P.L. 88-164.URL: https://www.govinfo.gov/content/pkg/STATUTE-77/pdf/STATUTE-77-Pg282.pdf

Declaration of Independence: a United States law from July 4, 1776. URL: https://www.ushistory.org/declaration/document

Education for All Handicapped Children Act: a United States law from July 29, 1975. P.L. 94142 URL: https://www.govtrack.us/congress/bills/94/s6/text

Individuals with Disabilities Education Improvement Act: a United States law from Decemrer 3, $2004 . \quad$ P.L. 108-446. URL: https://uscode.house.gov/view.xhtml?path=/prelim@ @itle20/chapter33/subchapter1\&editi on=prelim

Katsiyannis A., Reid R. Autism and Section 504: Rights and Responsibilities. Focus on Autism and Other Developmental Disabilities. Washington: SAGE Publications. 1999. v14 n 2 P. 66-72.

Psychiatric Association : Diagnostic and Statistical Manual of Mental Disorders, Fourth Edition. Washington : DC, American Psychiatric Association, 1994. 886 p.

Rehabilitation Act: a United States law from September 26, 1973. P.L. 93-112 URL: https://www.govtrack.us/congress/bills/93/hr8070/text

Rotatori A. F. History of Special Education. Bingley: Emerald Group Publishing. 2017. 390 p.

Winzer M.A. From integration to inclusion: a history of special education in the 20th century. Washington: Gallaudet University Press, 2009. 304 p.

Yell M., Lowrey K. No Child Left Behind and Students With Autism Spectrum Disorders. Focus on Autism and Other Developmental Disabilities. 2005. URL: https://www.researchgate.net/publication/245923995_No_Child_Left_Behind_and_Stude nts_With_Autism_Spectrum_Disorders

Model Eugenical Sterialization Law: a United States law from December 1922. URL: http://alexwellerstein.com/laughlin/

\section{REFERENCES:}

Burns, A. (2003) Handbook for Supplementary Aids and Services: A Best Practice and IDEA Guide. Springfield: Charles C Thomas Pub Ltd.

Community Mental Health Act: a United States (1963, October 31). P.L. 88-164.URL: https://www.govinfo.gov/content/pkg/STATUTE-77/pdf/STATUTE-77-Pg282.pdf

Declaration of Independence: a United States (1776, July 4). URL: https://www.ushistory.org/declaration/document

Education for All Handicapped Children Act: a United States (1975, July 29). P.L. 94-142 URL: https://www.govtrack.us/congress/bills/94/s6/text

Individuals with Disabilities Education Improvement Act: a United States (2004, Decemrer 3). P.L. 108-446. URL: https://uscode.house.gov/view.xhtml?path=/prelim@ title20/chapter33/subchapter1\&editi on=prelim

Katsiyannis, A. \& Reid, R. (1999) Autism and Section 504: Rights and Responsibilities. Focus on Autism and Other Developmental Disabilities v14 n 2 P. 66-72. Washington: SAGE Publications.

Psychiatric Association : Diagnostic and Statistical Manual of Mental Disorders (1994), Fourth Edition. Washington : DC, American Psychiatric Association.

Rehabilitation Act: a United States (1973, September 26) P.L. 93-112 URL: https://www.govtrack.us/congress/bills/93/hr8070/text

Rotatori, A. F. (2011) History of Special Education. Bingley: Emerald Group Publishing.

Winzer, M. A. (2009) From integration to inclusion: a history of special education in the 20th century. Washington: Gallaudet University Press. 
Yell, M. \& Lowrey K. (2005) No Child Left Behind and Students With Autism Spectrum Disorders. Focus on Autism and Other Developmental Disabilities.URL: https://www.researchgate.net/publication/245923995_No_Child_Left_Behind_and_Stude nts_With_Autism_Spectrum_Disorders.

Model Eugenical Sterialization Law: a United States (1922, December) URL: http://alexwellerstein.com/laughlin/

\begin{tabular}{ll}
\hline \multicolumn{1}{c}{ Інформація про автора: } & \multicolumn{1}{c}{ Information about the author: } \\
$\begin{array}{l}\text { Псарьова Марина Дмитрівна } \\
\text { ORSID: 0000-0002-0575-2629 }\end{array}$ & $\begin{array}{l}\text { Psarova Maryna Dmytrivna } \\
\text { ORSID: 0000-0002-0575-2629 }\end{array}$ \\
Аспірант кафедри загальної педагогіки та & PhD Student of Department of General \\
педагогіки вищої школи Харківського & Pedagogy and Higher School Pedagogy, \\
національного педагогічного університету & Ukraine, H. S. Skovoroda Kharkiv National \\
імені Г. С. Сковороди, вул. Валентинівська, & Pedagogical University, Street Valentynivska, \\
2, Харків, Україна, 61166. & 2, Kharkiv, Ukraine, 61166. \\
& \\
m.psareva.ua@gmail.com & m.psareva.ua@gmail.com
\end{tabular}

Цитуйте цю статтю як: Псарьова М.Д. Нормативно-правове забезпечення освіти дітей 3 порушеннями психічного розвитку у США в другій половині XX - на початку XXI століття. Теорія та методика навчання та виховання. 2020. № 48. С. 96-108.

DOI: https://doi.org/10.34142/23128046.2020.48.09

Дата надходження статті до редакції:

Стаття прийнята до друку: 